\title{
Inhibition of Bacillus anthracis growth by Australian native plants used traditionally as antibacterial medicines
}

\author{
Mitchell Henry Wright ${ }^{1}$, Anthony Carlson Greene ${ }^{1}$ and lan Edwin Cock ${ }^{1,2^{*}}$ \\ 'School of Natural Sciences, Nathan Campus, Griffith University, 170 Kessels Rd, Nathan, Queensland 4111, Australia. \\ 2Environmental Futures Research Institute, Nathan Campus, Griffith University, 170 Kessels Rd, Nathan, Queensland 4111, Australia.
}

\begin{abstract}
Introduction: Anthrax is a zoonotic disease caused by the bacterium $\mathrm{Ba}$ cillus anthracis. It is often fatal if left untreated. Many Australian plants have documented therapeutic properties as general antiseptics, inhibiting the growth of a wide variety of bacterial species. This study examines the ability of selected Australian plant extracts to inhibit B. anthracis growth. Methods: Solvent extracts were prepared using plants with documented ethnobotanical usage to treat bacterial infections, or published antibacterial activity. The extracts were investigated by disc diffusion assay for the ability to inhibit the growth of an environmental strain of $B$. anthracis. Their MIC values were determined to quantify and compare their efficacies. Toxicity was determined using the Artemia franciscana nauplii bioassay. Results: Methanolic and aqueous extracts of Eucalyptus baileyana and Eucalyptus major displayed potent antibacterial activity in the disc diffusion assay against $B$. anthracis. The methanolic extracts were particularly potent with MIC values as low as $290 \mu \mathrm{g} / \mathrm{mL}$ (E. major methanolic extract). Tasmannia insipidia and Tasmannia stipitata extracts also inhibited $B$. anthracis growth, albeit with low efficacy. The E. baileyana and $E$. major methanolic leaf extracts as well as the $E$. baileyana aqueous leaf extract induced significant mortality in the Artemia fransiscana bioassay, with $\mathrm{LC}_{50}$ values substantially $<1000 \mu \mathrm{g} / \mathrm{mL}$, indicating the toxicity of these extracts. Conclusion: The potent inhibitory bioactivity of the E. baileyana and E. major extracts against $B$. anthracis demonstrate their potential as medicinal agents in the treatment and prevention of anthrax. However, their toxicity indicates that their use may be limited to the treatment of the cutaneous form of the disease, or for sterilisation of infected sites.
\end{abstract}

Key words: Antibacterial activity, Anthrax, Bacillus anthracis, Eucalyptus, Scaevola spinescens, Tasmannia stipitata, Zoonotic, Traditional medicine.

\section{SUMMARY}

- Methanolic and aqueous Eucalyptus spp. extracts were potent inhibitors of Bacillus anthracis growth.

- The E. baileyana and E. major methanolic leaf extracts were particularly potent growth inhibitors with MIC's of 386 and $287 \mu \mathrm{g} / \mathrm{mL}$ respectively.
- Tasmannia spp. extracts had low growth inhibitory activity, with high MIC values.

- Melaleuca alternifolia and Scaevola spinescens were completely devoid of Bacillus anthracis growth inhibitory activity.

- The methanolic and aqueous E. baileyana and methanolic E. major leaf extracts displayed significant toxicity in the Artemia nauplii assay.

- All other extracts were non-toxic in the Artemia nauplii assay.

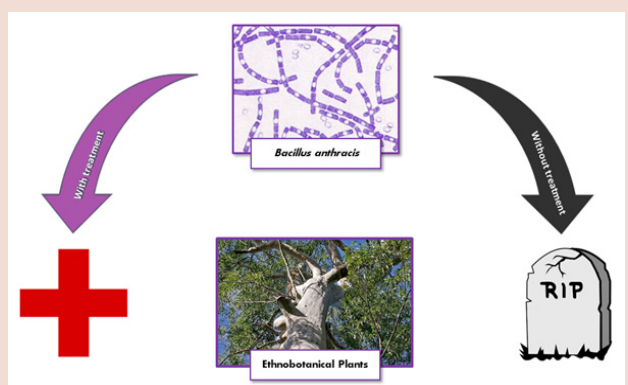

PICTORIAL ABSTRACT

Abbreviations used: DMSO: Dimethyl sulfoxide, $\mathrm{LC}_{50}$ : The concentration required to achieve $50 \%$ mortality, MIC: Minimum Inhibitory Concentration, PYE: Peptone Yeast Extract.

\section{Correspondence:}

Dr. Ian Edwin Cock, School of Natural Sciences and Environmental Futures Research Institute, Nathan Campus, Griffith University, 170 Kessels Rd, Nathan, Queensland 4111, Australia.

Phone no: +61 737357637 , Fax no: +61 737355282

Email: I.Cock@griffith.edu.au

DOI : 10.5530/pj.2015.6.13

\section{INTRODUCTION}

Bacillus anthracis is a facultative, spore-forming member of the Bacillaceae family and the etiological agent of the zoonotic disease anthrax. ${ }^{1}$ The bacterium has recently gained notoriety as a biological weapon, highlighting it as a focal point of bacteriological exploration as a matter of international urgency. B. anthracis has an extensive history in both modern warfare and in terrorism attacks, with the intentional infection and subsequent deaths of humans documented for over a century., ${ }^{2,3}$ However, aside from its potential applications to bioterrorism, B. anthracis is simply one of many Bacillus spp. found ubiquitously in terrestrial environments which indiscriminately infects animals and humans alike. Indeed, anthrax is well known within the agricultural community as the causative agent responsible for the indiscriminate, haphazard death of livestock and wildlife. ${ }^{4}$ As a result, extensive research has investigated the treatment and prevention of anthrax, as well as understanding the mechanisms and nature of the bacterium responsible for causing the lethal disease.
Human infection of anthrax can be divided into three forms: inhalation (pulmonary), cutaneous (direct contact to open wounds) and gastrointestinal (ingestion). ${ }^{5}$ Dissimilar to typical bacterial infections, anthrax is contracted through exposure to endospores rather than vegetative cells. Under environmental stresses, such as extreme surroundings or when deprived of necessary nutrients, $B$. anthracis produces spores that place it in a dormant-like state as a protection mechanism until conditions are once again favourable for cellular proliferation. ${ }^{6,7}$ Once internalised, the endospores resume normal metabolic functions and proliferation within the host ensues. Symptoms vary between disease types and if untreated anthrax has an extremely high mortality rate. ${ }^{8}$ Signs of anthrax infection range from flu-like symptoms (gastrointestinal and inhalational) to visible eschars (cutaneous), although any form can progress to fatal systemic anthrax. ${ }^{9}$ Anthrax meningitis may also develop and is indicated by the presence of blood in cerebrospinal fluid, shortly followed by loss of consciousness and ultimately death. ${ }^{10}$ 
The treatment and prevention of anthrax is principally achieved through vaccinations and antibiotic intervention. Vaccination against $B$. anthracis offers an effective means of disease prevention. However it is not routinely provided unless an individual is at risk of being exposed to the disease. Those at particular risk such as military personnel (in biological warfare), are regularly vaccinated to avoid infection. ${ }^{11}$ While considered the best method of prevention, vaccination is only $92.5 \%$ effective and must be administered well before infection occurs. ${ }^{12}$ Once the disease is contracted, the course of treatment is large doses of oral and/or intravenous antibiotics. However, due to the inherent risk that antibiotic treatment will result in resistant strains, the development and discovery of effective drugs is important in the long term management of the disease.

The search is ongoing for new antimicrobials to inhibit $B$. anthracis growth, either by (a) the design and synthesis of new agents, or (b) researching the repertoire of natural resources for as yet unrecognised or poorly characterised antimicrobial agents. ${ }^{13} \mathrm{~A}$ re-examination of traditional medicines for the treatment of bacterial pathogens is an attractive prospect as the antiseptic qualities of medicinal plants have been long recognised and recorded. Furthermore, there has recently been a revival of interest in herbal medications due to a perception that there is a lower incidence of adverse reactions to plant preparations compared to synthetic pharmaceuticals. Probing of natural resources for compounds with known antimicrobial properties offers a novel approach to the treatment of anthrax.

Recent studies have demonstrated the potent inhibitory activity of several Australian plants against a wide panel of medicinally important bacteria. ${ }^{14-17}$ Furthermore, many Australian plants have well known antiseptic properties. ${ }^{18}$ Several plant species were selected for B. anthracis growth inhibitory activity screening based on their usage in traditional medicine systems and/or their reported antibacterial activities (Table 1). Plants of the genus Eucalyptus are particularly well known for their antiseptic properties due to their high 1, 8-cineol contents. ${ }^{18-21}$ The first Australians crushed the leaves and inhaled the volatiles to treat coughs and colds. ${ }^{18,19}$ Fresh leaves or decoctions prepared from the leaves were also used as wound antiseptics and to treat skin and throat infections. Several in vitro studies have demonstrated the growth inhibitory properties of Eucalyptus baileyana and Eucalyptus major extracts towards a panel of bacterial species. ${ }^{20,21}$ Indeed, these studies reported both species to strongly inhibit the growth of the bacterium Bacillus cereus, which shares a close taxonomic relationship with B. anthracis (>99\% 16S rRNA sequence homology), indicating their potential to inhibit $B$. anthracis growth. Essential oils prepared from Eucalyptus leaves remain a popular antiseptic agent, not only in Australia, but are also commonly sold in pharmacies internationally.

Melaleuca spp. also have well established antibacterial properties (Table 1). 'Tea-tree' essential oils are used as antiseptics in a similar manner as the Eucalyptus essential oils. ${ }^{18,19}$ Melaleuca spp. essential oils are rich also in 1,8-cineol, as well as other mono and sesquiterpenoids. ${ }^{18}$ Laboratory studies have reported broad spectrum antibacterial activity for Melaleuca quinquenervia and Melaleuca alternifolia, although neither species inhibited the growth of $B$. cereus in those studies. ${ }^{20}$ Scaevola spinescens is also used in several Australian Aboriginal medicinal systems (Table 1). ${ }^{18,19}$ Infusions of the roots were used to treat stomach pain and urinary disorders. A decoction of the stems material is applied externally to treat boils, rashes and skin disorders. Burning the whole plant produces fumes which are inhaled to treat coughs and colds. The leaves and twigs may also be steamed and sores and skin disorders treated by exposure to the steam. Bacterial infections are responsible for many of these disorders. Recent studies reported potent broad spectrum bacterial growth inhibitory activity for $S$. spinescens extracts, ${ }^{22}$ however also reported that the extracts were ineffective inhibitors of $B$. cereus growth.

Plants from the genus Tasmannia (family Winteraceae) have culinary uses, although there is no record of their usage in traditional Australian medicinal systems (Table 1). ${ }^{23}$ Recent studies have reported potent broad spectrum antimicrobial activity for Tasmannia lanceolata ${ }^{24}$ and Tasmannia stipitata extracts in vitro. ${ }^{14}$ Interestingly, moderate to good $B$. cereus growth inhibitory activity was reported for both Tasmannia species. Furthermore, T. lanceolata ${ }^{25}$ and T. stipitata ${ }^{14}$ have also been reported to inhibit the proliferation of the gastrointestinal protozoal parasite Giardia duodenalis. ${ }^{14,25}$ To our knowledge, there no similar studies reporting therapeutic properties for T. insipidia. Despite this relative wealth of information documenting antibacterial Australian plants, many are yet to be tested for the ability toinhibit $B$. anthracis growth. The current study examines the growth inhibitory activity of extracts of selected Australian

Table 1: The ethnobotanical usage and common names of the native Australian plant species tested in this study

\begin{tabular}{|c|c|c|c|c|c|}
\hline Plant Species & Common Name & Part Used Medicinally & $\begin{array}{l}\text { Part Used in } \\
\text { This Study }\end{array}$ & Medicinal Use & References \\
\hline $\begin{array}{c}\text { Eucalyptus baileyana } \\
\text { F. Muell. }\end{array}$ & $\begin{array}{c}\text { Bailey's stringy } \\
\text { bark }\end{array}$ & $\begin{array}{l}\text { The leaves and kinos of many } \\
\text { Eucalyptus spp. are used to } \\
\text { prepare extracts, decoctions or as } \\
\text { essential oils. }\end{array}$ & leaves & $\begin{array}{l}\text { Inhalation of the volatiles from essential oils or } \\
\text { from crushed leaves is used to treat coughs and } \\
\text { colds. The leaves, oils or infusions produced } \\
\text { from the leaves are also used as wound } \\
\text { antiseptics, or to treat skin or throat infections. } \\
\text { This species has been shown to have potent } \\
\text { broadspectrum antibacterial activity in vitro. }\end{array}$ & $18-21$ \\
\hline $\begin{array}{l}\text { Eucalyptus major } \\
\text { (Maiden) Blakely }\end{array}$ & $\begin{array}{l}\text { Queensland grey } \\
\text { gum }\end{array}$ & $\begin{array}{l}\text { The leaves and kinos of many } \\
\text { Eucalyptus spp. are used to } \\
\text { prepare extracts, decoctions or as } \\
\text { essential oils. }\end{array}$ & $\begin{array}{c}\text { leaves and } \\
\text { flowers }\end{array}$ & $\begin{array}{l}\text { Inhalation of the volatiles from essential oils or } \\
\text { from crushed leaves is used to treat coughs and } \\
\text { colds. The leaves, oils or infusions produced } \\
\text { from the leaves are also used as wound } \\
\text { antiseptics, or to treat skin or throat infections. } \\
\text { This species has been shown to have potent } \\
\text { broadspectrum antibacterial activity in vitro. }\end{array}$ & $18-21$ \\
\hline Melalueca alternifolia & $\begin{array}{c}\text { narrow leaved } \\
\text { paperbark, } \\
\text { narrow leaved } \\
\text { teatree, narrow } \\
\text { leaved ti-tree, } \\
\text { snow in summer }\end{array}$ & $\begin{array}{l}\text { The leaves of many Melaleuca } \\
\text { spp. are used to prepare extracts, } \\
\text { decoctions or as essential oils. }\end{array}$ & leaves & $\begin{array}{l}\text { Inhalation of the volatiles from essential oils or } \\
\text { from crushed leaves is used to treat coughs and } \\
\text { colds. The leaves, oils or infusions produced } \\
\text { from the leaves are also used as wound } \\
\text { antiseptics, or to treat skin or throat infections. } \\
\text { This species has been shown to have potent } \\
\text { broadspectrum antibacterial activity in vitro. }\end{array}$ & $18-20$ \\
\hline
\end{tabular}




\begin{tabular}{|c|c|c|c|c|c|}
\hline $\begin{array}{c}\text { Scaevola spinescens } \\
\text { R.Br. }\end{array}$ & $\begin{array}{l}\text { currant bush, } \\
\text { maroon bush, } \\
\text { fanflower, prickly } \\
\text { fanflower }\end{array}$ & $\begin{array}{c}\text { The whole plant was used } \\
\text { medicinally by the first } \\
\text { Australians. }\end{array}$ & leaves & $\begin{array}{l}\text { An infusion of the roots was used to treat } \\
\text { stomach pain and urinary disorders; a } \\
\text { decoction of the stem was used to treat boils, } \\
\text { rashes and skin disorders; the whole plant was } \\
\text { burnt and fumes were inhaled to treat colds; } \\
\text { leaves and twigs were steamed and sores and } \\
\text { skin disorders were treated by exposure to the } \\
\text { steam. }\end{array}$ & $18,22,26,27$ \\
\hline $\begin{array}{c}\text { Tasmannia insipidia } \\
\text { R.Br. }\end{array}$ & brush pepperbush & $\begin{array}{l}\text { leaves, berries and seeds are used } \\
\text { for culinary purposes. }\end{array}$ & leaves & $\begin{array}{c}\text { No record of usage in traditional medicine } \\
\text { systems, although many Tasmannia spp. have } \\
\text { high antioxidant contents. Furthermore, } \\
\text { T. insipida is related to T. lanceolata and T. } \\
\text { stipitata (which have documented medicinal } \\
\text { properties). }\end{array}$ & $14,18,23,24,28$ \\
\hline $\begin{array}{c}\text { Tasmannia stipitata } \\
\text { R.Br. }\end{array}$ & $\begin{array}{l}\text { Dorrigo pepper, } \\
\text { Northern } \\
\text { pepperbush }\end{array}$ & leaves, berries and seeds & $\begin{array}{c}\text { leaves and } \\
\text { berries }\end{array}$ & $\begin{array}{l}\text { No record of usage in traditional medicine } \\
\text { systems, although many Tasmannia spp. have } \\
\text { high antioxidant contents. Furthermore, } T \text {. } \\
\text { stipitata is related to T. lanceolata (which } \\
\text { has well documented medicinal properties). } \\
\text { Broad-spectrum antibacterial activity has been } \\
\text { demonstrated in vitro. }\end{array}$ & $14,18,23,24,28$ \\
\hline
\end{tabular}

plants which prevent the growth of other bacteria against B. anthracis with the aim of determining new leads for the prevention and treatment of anthrax.

\section{MATERIALS AND METHODS}

\section{Plant source and extraction}

Air dried Tasmannia insipidia and Tasmannia stipitata leaves and berries were supplied and verified by the Queensland Bushfoods Association, Australia. Scaevola spinescens was supplied by Jeannie Crago of Outback Books Australia (a commercial supplier of S. spinescens tea) as a predried and course milled whole plant material. Eucalyptus baileyana, Eucalyptus major and Melaleuca alternifolia plant materials were collected from Toohey Forest, Brisbane and were identified with reference to a taxonomic key to Toohey Forest plants. ${ }^{29}$ Voucher samples of all plant specimens have been stored in the School of Natural Sciences, Griffith University. The plant materials were thoroughly dried in a Sunbeam food dehydrator and the dried plant materials were stored at $-30^{\circ} \mathrm{C}$. Prior to use, the plant materials were thawed and freshly ground to a coarse powder. Individual $1 \mathrm{~g}$ quantities of the ground plant material were weighed into separate tubes and $50 \mathrm{~mL}$ of methanol or water were added. All solvents were obtained from Ajax and were AR grade. The ground plant materials were individually extracted in each solvent for 24 hours at $4^{\circ} \mathrm{C}$ with gentle shaking. The extracts were subsequently filtered through filter paper (Whatman No. 54) under vacuum, followed by drying by rotary evaporation in an Eppendorf concentrator 5301. The resultant dry extract was weighed and redissolved in $10 \mathrm{~mL}$ deionised water (containing $1 \%$ DMSO).

\section{Qualitative phytochemical studies}

Phytochemical analysis of the extracts for the presence of saponins, phenolic compounds, flavonoids, polysteroids, triterpenoids, cardiac glycosides, anthraquinones, tannins and alkaloids was conducted by previously described assays. ${ }^{30-32}$

\section{Antibacterial screening}

\section{Environmental Bacillus anthracis strain}

An environmental strain of Bacillus anthracis was isolated and used in these studies. The bacterium was originally isolated from a water sample taken from Paralana hot springs ( $\left.30^{\circ} 17^{\prime} 49^{\prime \prime} \mathrm{S}, 139^{\circ} 44^{\prime} 15^{\prime \prime} \mathrm{E}\right)$, South Aus- tralia. Isolation was achieved through successive culturing steps using a modified Peptone/Yeast Extract (PYE) agar as previously described. ${ }^{13}$ Sequence analysis of the environmental isolate generated a contig of 1428 bp which was revealed to be $99.92 \%$ similar to B. anthracis by EzTaxon and designated as Bacillus anthracis strain PMO. The GenBank accession number for the $16 \mathrm{~S}$ rRNA gene sequence for the isolate is KR003287.

\section{Evaluation of antimicrobial activity}

Antimicrobial activity of all plant extracts was determined using a modified disc diffusion assay. ${ }^{30-32}$ Briefly, $100 \mu \mathrm{L}$ of the test bacteria were grown in $10 \mathrm{~mL}$ of fresh nutrient broth media until they reached a count of approximately $10^{8}$ cells $/ \mathrm{mL}$. An amount of $100 \mu \mathrm{L}$ of bacterial suspension was spread onto nutrient agar plates. The extracts were tested for antibacterial activity using $6 \mathrm{~mm}$ sterilised filter paper discs. Discs were impregnated with $10 \mu \mathrm{L}$ of the test sample, allowed to dry and placed onto inoculated plates. The plates were allowed to stand at $4^{\circ} \mathrm{C}$ for 2 hours before incubation at $30^{\circ} \mathrm{C}$ for 24 hours. The diameters of the inhibition zones were measured in millimetres. All measurements were to the closest whole millimetre. Each assay was performed in at least triplicate. Mean values $( \pm$ SEM) are reported in this study. Standard discs of penicillin-G $(2 \mu \mathrm{g})$ and chloramphenicol $(10 \mu \mathrm{g})$ were obtained from Oxoid Australia Ltd. and served as positive controls for antibacterial activity. Filter discs impregnated with $10 \mu \mathrm{L}$ of distilled water were used as a negative control.

\section{Minimum inhibitory concentration (MIC) determination}

The Minimum inhibitory concentration (MIC) of the extracts was determined as previously described. ${ }^{30-32}$ Briefly, the plant extracts were diluted in deionised water and tested across a range of concentrations. Discs were impregnated with $10 \mu \mathrm{L}$ of the test dilutions, allowed to dry and placed onto inoculated plates. The assay was performed as outlined above and graphs of the zone of inhibition versus concentration were plotted for each extract. Linear regression was used to calculate the MIC values.

\section{Toxicity screening}

\section{Reference toxin for toxicity screening}

Potassium dichromate $\left(\mathrm{K}_{2} \mathrm{Cr}_{2} \mathrm{O}_{7}\right)$ (AR grade, Chem-Supply, Australia) was prepared as a $4 \mathrm{mg} / \mathrm{mL}$ solution in distilled water and was serially diluted in artificial seawater for use in the Artemia franciscana nauplii bioassay. 
Table 2: The mass of dried extracted material, the concentration after resuspension in deionised water, qualitative phytochemical screenings of the plant extracts

\begin{tabular}{|c|c|c|c|c|c|c|c|c|c|c|c|c|c|c|c|c|c|}
\hline $\begin{array}{l}\stackrel{\tilde{u}}{\tilde{U}} \\
\text { ڤँ }\end{array}$ & 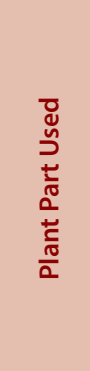 & 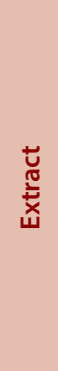 & 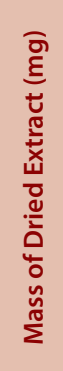 & 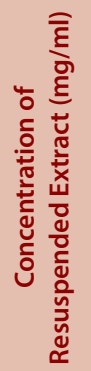 & 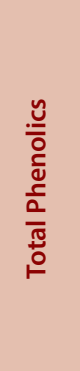 & 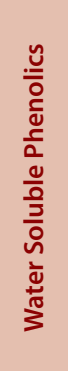 & 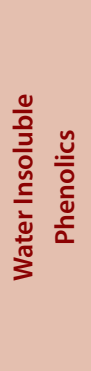 & 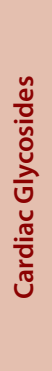 & 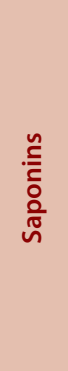 & 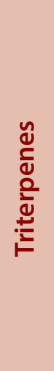 & 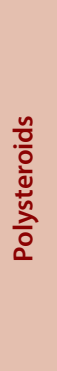 & 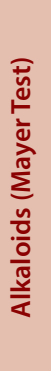 & 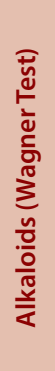 & $\begin{array}{l}\frac{n}{0} \\
\frac{0}{0} \\
\frac{0}{0} \\
\frac{\pi}{4}\end{array}$ & 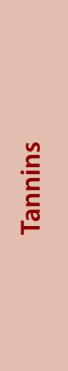 & 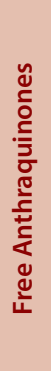 & 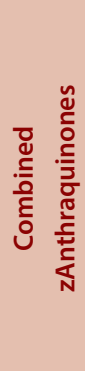 \\
\hline E. baileyana & leaf & M & 143 & 14.3 & +++ & +++ & + & - & + & - & - & - & - & + & ++ & - & - \\
\hline E. baileyana & leaf & $\mathrm{W}$ & 125 & 12.5 & +++ & +++ & + & - & + & - & - & - & - & ++ & + & - & - \\
\hline E. major & leaf & $\mathrm{M}$ & 280 & 28 & +++ & +++ & + & - & + & - & - & - & - & ++ & ++ & - & - \\
\hline E. major & leaf & $\mathrm{W}$ & 222 & 22.2 & +++ & +++ & + & - & + & - & - & - & - & +++ & + & - & - \\
\hline E. major & flower & $\mathrm{M}$ & 324 & 32.4 & +++ & +++ & + & - & + & - & - & - & - & + & + & - & - \\
\hline E. major & flower & $\mathrm{W}$ & 241 & 24.1 & +++ & +++ & + & - & + & - & - & - & - & ++ & + & - & - \\
\hline M. alternifolia & leaf & $\mathrm{M}$ & 237 & 23.7 & +++ & +++ & + & - & ++ & - & - & - & - & +++ & +++ & - & - \\
\hline M. alternifolia & leaf & $\mathrm{W}$ & 163 & 16.3 & +++ & +++ & + & - & + & - & - & - & - & ++ & +++ & - & - \\
\hline S. spinescens & leaf & $\mathrm{M}$ & 116 & 11.6 & +++ & ++ & - & - & + & - & - & + & - & ++ & ++ & - & - \\
\hline S. spinescens & leaf & $\mathrm{W}$ & 210 & 21 & +++ & ++ & - & - & + & - & - & - & - & ++ & +++ & - & - \\
\hline T. insipidia & leaf & $\mathrm{M}$ & 221 & 22.1 & +++ & ++ & + & - & ++ & + & - & - & - & ++ & - & - & - \\
\hline T. insipidia & leaf & $\mathrm{W}$ & 184 & 18.4 & +++ & ++ & + & - & + & + & - & - & - & ++ & - & - & - \\
\hline T. stipitata & leaf & $\mathrm{M}$ & 293 & 29.3 & +++ & +++ & ++ & - & +++ & + & - & - & - & +++ & - & - & - \\
\hline T. stipitata & leaf & $\mathrm{W}$ & 232 & 23.2 & +++ & +++ & +++ & - & ++ & + & - & - & - & +++ & - & - & - \\
\hline T. stipitata & berry & $\mathrm{M}$ & 279 & 27.9 & +++ & +++ & ++ & - & +++ & + & - & - & - & +++ & - & - & - \\
\hline T. stipitata & berry & $\mathrm{W}$ & 207 & 20.7 & +++ & +++ & +++ & - & ++ & + & - & - & - & +++ & - & - & - \\
\hline
\end{tabular}

+++ indicates a large response; ++ indicates a moderate response; + indicates a minor response; - indicates no response in the assay.

\section{Artemia franciscana nauplii toxicity screening}

Toxicity was tested using a modified Artemia franciscana nauplii lethality assay. ${ }^{33-35}$ Briefly, $400 \mu \mathrm{L}$ of seawater containing approximately 43 (mean $43.2, n=155$, SD 14.5) A. franciscana nauplii were added to wells of a 48 well plate and immediately used for the bioassay. A volume of $400 \mu \mathrm{L}$ of diluted plant extracts or the reference toxin were transferred to the wells and incubated at $25 \pm 1{ }^{\circ} \mathrm{C}$ under artificial light (1000 Lux). A negative control ( $400 \mu \mathrm{L}$ seawater) was run in triplicate for each plate. All treatments were performed in at least triplicate. The wells were checked at regular intervals and the number of dead counted. The nauplii were considered dead if no movement of the appendages was observed within 10 seconds. After $24 \mathrm{~h}$, all nauplii were sacrificed and counted to determine the total \% mortality per well. The LC $_{50}$ with $95 \%$ confidence limits for each treatment was calculated using probit analysis.

\section{Statistical analysis}

Data are expressed as the mean \pm SEM of at least three independent experiments.

\section{RESULTS}

\section{Liquid extraction yields and qualitative phytochemical screening}

Extraction of $1 \mathrm{~g}$ of the various dried Australian plant materials with the solvents yielded dried plant extracts ranging from $116 \mathrm{mg}$ (S. spinescens methanolic extract) to $324 \mathrm{mg}$ (E. major methanolic flower extract)
(Table 2). With the exception of the S. spinescens extracts, the methanolic extracts generally gave higher yields of dried extracted material compared with the corresponding aqueous extracts. The dried extracts were resuspended in $10 \mathrm{~mL}$ of deionised water (containing 1\% DMSO) resulting in the extract concentrations shown in Table 2.

Qualitative phytochemical studies showed that the methanolic and aqueous extracts generally had a wide range of phytochemicals (Table 2). Both methanol and water extracted high levels of phenolics (water soluble) for all plant materials. Moderate to high flavonoid contents were present in most extracts. Similar levels of tannins were evident in all extracts except the Tasmannia spp. extracts, which were devoid of detectable tannins. Low to moderate levels of saponins were seen in all Eucalyptus spp. extracts as well as the M. alternifolia and S. spinescens extracts. All extracts were devoid of detectable levels of alkaloids, polysterols, cardiac glycosides and athraquinones.

\section{Antimicrobial activity}

To determine the ability of the crude plant extracts to inhibit the growth of $B$. anthracis, aliquots $(10 \mu \mathrm{L})$ of each extract were screened using a disc diffusion assay. The bacterial growth was inhibited by 11 of the 16 extracts screened (68.8\%) (Figure 1). The E. baileyana and E. major methanolic leaf extracts were the most potent inhibitor of $B$. anthracis growth (as judged by zone of inhibition), with inhibition zones of $15.7 \pm 0.6 \mathrm{~mm}$ and 15.3 $\pm 0.6 \mathrm{~mm}$ respectively. This compares favourably with the penicillin and chloramphenicol controls, which had zones of inhibition of $8.3 \pm 0.6$ and $15.6 \pm 0.6 \mathrm{~mm}$ respectively. All of the Eucalyptus spp. extracts displayed potent growth inhibition with $>10 \mathrm{~mm}$ zones of inhibition (with the ex- 


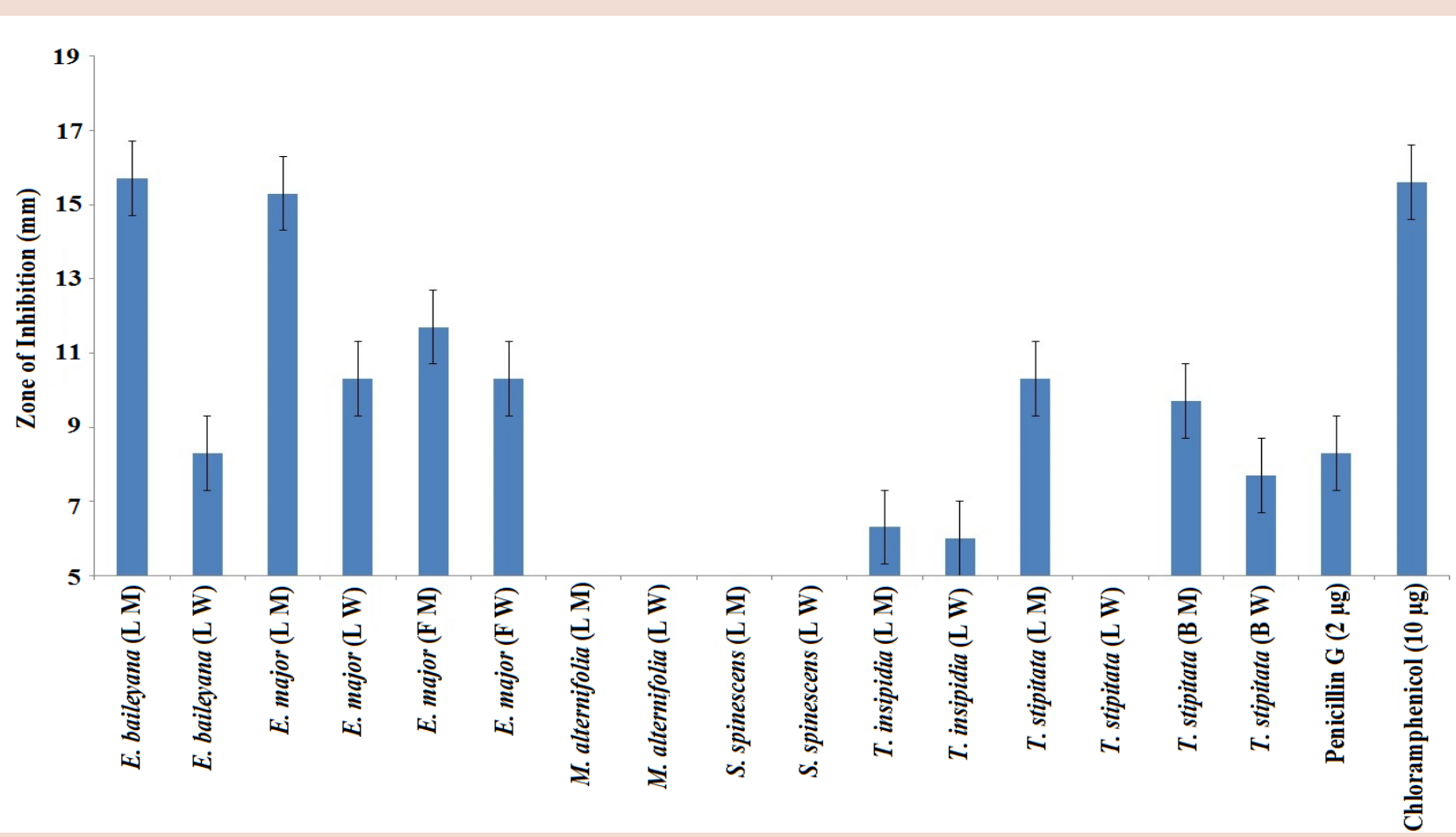

Figure 1: Growth inhibitory activity of plant extracts against the $B$. anthracis environmental isolate measured as zones of inhibition ( $\mathrm{mm}$ ). $\mathrm{L}=\mathrm{leaf}$; $\mathrm{F}=\mathrm{flower}$; $\mathrm{B}=$ berry; $\mathrm{M}=$ methanolic extract; $\mathrm{W}=$ =aqueous extract

Results are expressed as mean zones of inhibition \pm SEM

Table 3: Minimum inhibitory concentration $(\mu \mathrm{g} / \mathrm{mL})$ of the plant extracts and $L_{50}$ values $(\mu \mathrm{g} / \mathrm{mL})$ in the Artemia nauplii bioassay.

\begin{tabular}{ccccc}
\hline Species & Part & Extract & $\mathrm{MIC}(\mu \mathrm{g} / \mathrm{mL})$ & $\mathrm{LC}_{50}(\mu \mathrm{g} / \mathrm{mL})$ \\
\hline E. baileyana & leaf & methanol & 386 & 455 \\
E. baileyana & leaf & water & 1573 & 897 \\
E. major & leaf & methanol & 287 & 793 \\
E. major & leaf & water & 1157 & 1146 \\
E. major & flower & methanol & 1733 & 1154 \\
E. major & flower & water & 1193 & - \\
M. alternifolia & leaf & methanol & - & - \\
M. alternifolia & leaf & water & - & - \\
S. spinescens & leaf & methanol & - & - \\
S. spinescens & leaf & water & - & 1467 \\
T. insipidia & leaf & methanol & $>10,000$ & 1687 \\
T. insipidia & leaf & water & $>10,000$ & 1813 \\
T. stipitata & leaf & methanol & $>10,000$ & 1487 \\
T. stipitata & leaf & water & - & - \\
T. stipitata & berry & methanol & $>10,000$ & 1530 \\
T. stipitata & berry & water & $>10,000$ & 82 \\
Potassium Dichromate & - & - & \\
\hline
\end{tabular}

Numbers indicate the mean MIC and $\mathrm{LC}_{50}$ values of triplicate determinations. -indicates no bacterial growth inhibition was evident, or that an $\mathrm{LC}_{50}$ value could not be obtained as the mortality did not reach $50 \%$ for any dose tested.

ception of E. baileyana aqueous extract, with a zone of inhibition of $8.3 \pm$ $0.6 \mathrm{~mm}$ ). The methanolic and aqueous T. stipitata extracts also displayed moderate to good growth inhibitory activity $(7.7-10.3 \mathrm{~mm})$. The M. alternifolia and S. spinescens methanolic and aqueous extracts were completely devoid of B. anthracis growth inhibitory activity.
The antimicrobial efficacy was further quantified by determining the MIC values (Table 3). The methanolic E. baileyana and E. major leaf extracts were particularly effective at inhibiting microbial growth, with MIC values against $B$. anthracis $<400 \mu \mathrm{g} / \mathrm{mL}(<4 \mu \mathrm{g}$ impregnated in the disc). The aqueous and methanolic E. major flower and the aqueous 


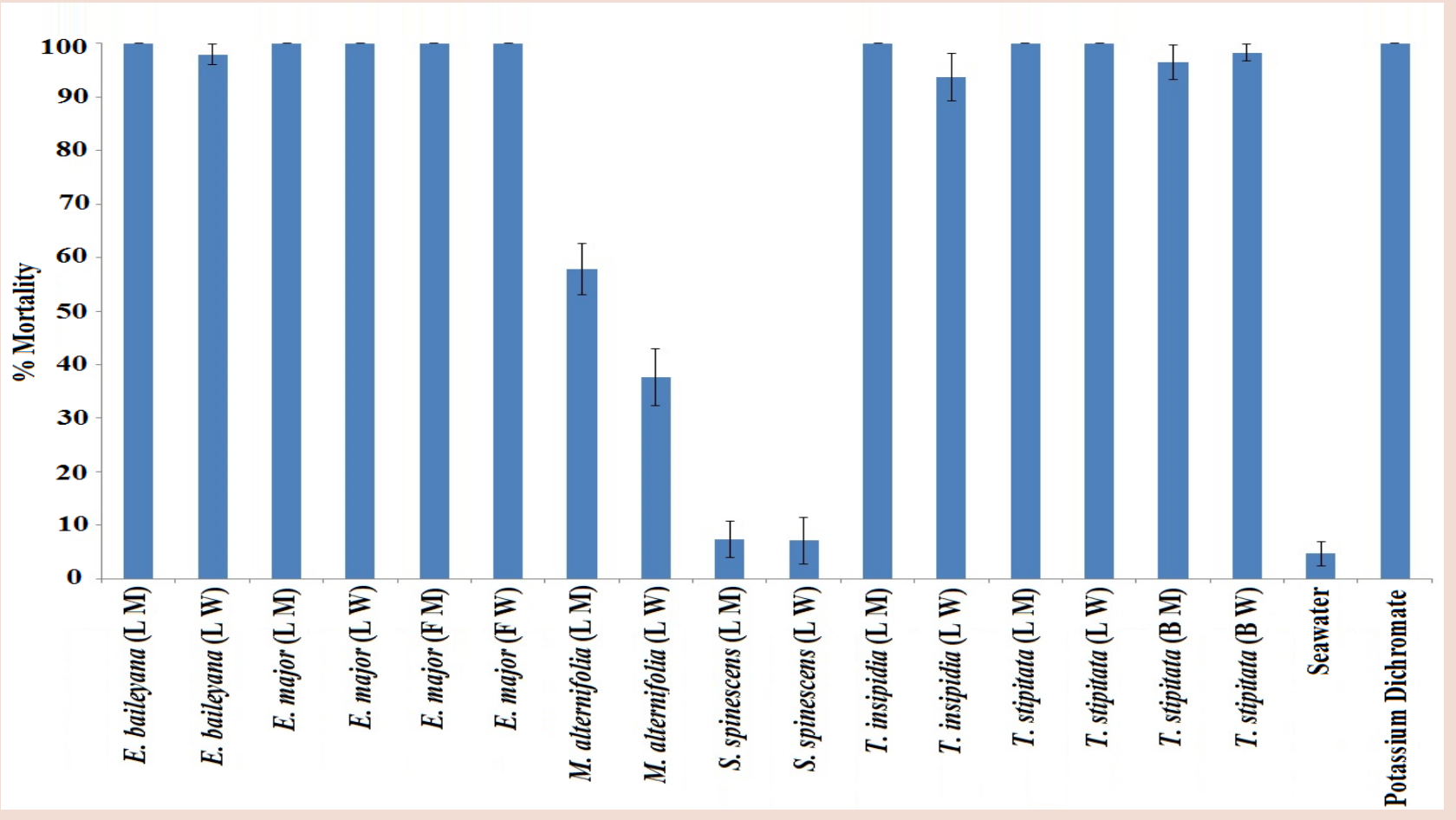

Figure 2: The lethality of the Australian plant extracts $(2000 \mu \mathrm{g} / \mathrm{mL})$ and the potassium dichromate $(1000 \mu \mathrm{g} / \mathrm{mL})$ and seawater controls towards Artemia franciscana nauplii after 24 hours exposure. $\mathrm{L}=$ leaf; $\mathrm{F}=$ flower; $\mathrm{B}=$ berry; $\mathrm{M}=$ methanolic extract; $\mathrm{W}=$ aqueous extract

Results are expressed as mean zones of inhibition \pm SEM

E. baileyana and E. major leaf extracts, whilst less potent $B$. anthracis growth inhibitors, also displayed good growth inhibition with MIC's $<2000 \mu \mathrm{g} / \mathrm{mL}(<20 \mu \mathrm{g}$ impregnated in the disc). All other plant extracts were either inactive or showed only low inhibitory activity with MIC values $>10,000 \mu \mathrm{g} / \mathrm{mL}$.

\section{Quantification of toxicity}

All extracts were initially screened at $2000 \mu \mathrm{g} / \mathrm{mL}$ in the assay (Figure 2). For comparison, the reference toxin potassium dichromate $(1000 \mu \mathrm{g} /$ $\mathrm{mL}$ ) was also tested in the bioassay. The potassium dichromate reference toxin was rapid in its onset of mortality, inducing nauplii death within the first 3 hours of exposure and 100\% mortality was evident following 4-5 hours (results not shown). With the exception of the M. alternifolia aqueous extract and the aqueous and methanolic S. spinescens extracts, the plant extracts displayed $>50 \%$ mortality rates at $24 \mathrm{~h}$.

To further quantify the effect of toxin concentration on the induction of mortality, the extracts were serially diluted in artificial seawater to test across a range of concentrations in the Artemia nauplii bioassay. Table 3 shows the $\mathrm{LC}_{50}$ values of the extracts towards $A$. franciscana. No $\mathrm{LC}_{50}$ values are reported for $S$. spinescens extracts or for the M. alternifolia aqueous extract as $<50 \%$ mortality was seen for all concentrations tested. Significant toxicity was noted for both E. baileyana extracts as well as the E. major leaf methanolic extract with $\mathrm{LC}_{50}$ values substantially $<1000 \mu \mathrm{g} /$ $\mathrm{mL}$. All other extracts were determined to be nontoxic, with $\mathrm{LC}_{50}$ values substantially greater than $1000 \mu \mathrm{g} / \mathrm{mL}$ following $24 \mathrm{~h}$ exposure. Extracts with an $\mathrm{LC}_{50}$ of greater than $1000 \mu \mathrm{g} / \mathrm{mL}$ towards Artemia nauplii have been defined as being nontoxic. ${ }^{34}$

\section{DISCUSSION}

Previous studies have reported potent bacterial growth inhibitory activity for all of the native Australian plant species screened in our study against different pathogenic bacterial species. ${ }^{14,20-22,28}$ S. spinescens leaves ${ }^{22}$ and the leaves and berries of several Tasmannia spp..$^{14,16,24,28}$ Have been reported to have inhibitory activity against extensive panels of pathogenic bacteria. Each of these species was equally effective at inhibiting the growth of Gram positive and Gram negative bacteria. In contrast, the bacterial growth inhibitory properties of the Eucalyptus spp. and of M. alternifolia have been reported against a narrower range of pathogenic bacteria. ${ }^{20,21}$ Interestingly, whilst $B$. anthracis was not tested in any of the previous studies, E. baileyana and E. major extracts were reported to strongly inhibit the growth of the related bacterial species $B$. cereus. ${ }^{20,21} B$. cereus is very closely related to $B$. anthracis with $>99 \% 16 \mathrm{~S}$ rRNA gene sequence homology. ${ }^{36}$ Indeed, some bacterial taxonomists believe that $B$. anthracis, B. cereus, $B$. thuringiensis, B. mycoides, B. pseudomycoides and B. weinstephanensis should be classified as a single species under current standards ( $>97 \% 16 \mathrm{~S}$ rRNA sequence homology) and are only classified as separate species as a result of the different diseases that they cause. ${ }^{37-39}$ It is therefore perhaps not surprising that the E. baileyana and E. major extracts screened in our study displayed growth inhibitory activity towards $B$. anthracis.

Whilst an investigation of the phytochemistry of the Eucalyptus spp. extracts was beyond the scope of our study, plants of the genus Eucalyptus are well known for their high terpenoid contents. In particular, high 1, 8 -cineol contents was reported for several Eucalyptus spp..$^{18}$ Potent bacterial growth inhibitory activity has been reported for 1, 8-cineol against a panel of pathogenic bacteria, including $B$. cereus. ${ }^{40}$ Another study reported MIC values for 1, 8-cineol against Staphylococcus aureus, Pseudomonas aeruginosa and Escherichia coli of between 16 and $256 \mu \mathrm{g} / \mathrm{mL} .^{41}$ That study did not screen 1, 8-cineol against Bacillus spp. Eucalyptus spp. are also rich in a variety of other mono and sesquiterpenoids. ${ }^{18}$ Some of these terpenoids have been previously reported to have potent broad spectrum antibacterial activity ${ }^{23}$ and therefore may contribute to the inhibitory activity against B. anthracis.

Another commonality between the inhibitory Eucalyptus spp. extracts was that all contained relatively high levels of flavonoids and tannins. 
Many studies have reported potent antibacterial activities for a wide variety of flavonoids. ${ }^{42}$ Whilst we were unable to find any reports of $B$. anthracis growth inhibitory activity of flavonoids, they have been reported to inhibit growth of the closely related species $B$. cereus.$^{43}$ Similarly, a number of tannin compounds have bacterial growth inhibitory activity. Gallo tannins have been reported to inhibit the growth of a broad spectrum of bacterial species ${ }^{44}$ through a variety of mechanisms including binding cell surface molecules including lipotoichoic acid and proline-rich cell surface proteins, ${ }^{45,46}$ and by inhibiting glucosyl transferase enzymes. ${ }^{47}$ Elligitannins are also highly potent inhibitors of bacterial growth, with MIC values as low as $62.5 \mu \mathrm{g} / \mathrm{ml} .^{44,46}$ Ellagitannins have also been reported to function via several antibiotic mechanisms including interaction with cytoplasmic oxidoreductases and by disrupting bacterial cell walls. ${ }^{44,46}$ Thus, it is likely that multiple compounds within the Eucalyptus spp. extracts are contributing to the growth inhibition of $B$. anthracis.

The findings reported here demonstrate that the majority of the Australian plant extracts tested in our study were nontoxic towards Artemia franciscana nauplii. However, the most promising B. anthracis growth inhibitory extracts (methanolic and aqueous E. baileyana and methanolic E. major leaf extracts) displayed substantial toxicity, with $\mathrm{LC}_{50}$ values as low as $455 \mu \mathrm{g} / \mathrm{mL}$.Extracts with $\mathrm{LC}_{50}$ values $<1000 \mu \mathrm{g} / \mathrm{ml}$ towards $A r$ temia nauplii are defined as being toxic, ${ }^{34}$ which may impact on their therapeutic potential. As the $\mathrm{LC}_{50}$ values are within the therapeutic ranges that would be required for $B$. anthracis growth inhibition (determined by MIC), studies using human cell lines are required to further evaluate the safety of these extracts. However, even if the Eucalyptus spp. extracts are subsequently deemed unsafe for ingestion, they may still be useful $B$. anthracis growth inhibitory agents. The most prevalent form of anthrax is cutaneous infection via skin cuts and abrasions. ${ }^{48}$ Topical application of the extracts may prove effective in treating this form of the disease. Alternatively, the Eucalyptus spp. extracts may be useful for disinfecting contaminated sites (e.g. where infected livestock have perished), or for sterilising surfaces that have been in contact with $B$. anthracis. Furthermore, whilst the results of our study are promising, it must be noted that the growth inhibitory studies screened against vegetative cells. As Bacillus spp. are spore formers, further studies are required to determine whether extracts with $B$. anthracis growth inhibitory activity also affect bacterial growth from the spores.

\section{CONCLUSION}

The results of this study demonstrate the potential of the Eucalyptus spp. extracts to block the growth of B. anthracis. However, the toxicity of these extracts may limit their clinical usage. Further studies aimed at the purification of the bioactive components are needed to examine the mechanisms of action of these agents.

\section{ACKNOWLEDGEMENT}

Financial support for this work was provided by the Environmental Futures Research Institute and the School of Natural Sciences, Griffith University, Australia.

\section{CONFLICT OF INTEREST}

The authors report no conflicts of interest.

\section{REFERENCES}

1. Petosa C, Collier RJ, Klimpel KR, et al. Crystal structure of the anthrax toxin protective antigen. Nature 1997; 385(6619): 833-8.

2. Christopher GW, Cieslak TJ, Pavlin JA, Eitzen EM. Biological Warfare. A historical perspective. JAMA. 1997; 278(5): 412-7.

3. Inglesby TV, Henderson DA, Bartlett JG, et al. Anthrax as a Biological Weapon. JAMA. 1999; 281(18): 1735-45.
4. Keim P, Price LB, Klevytska AM, et al. Multiple-LocusVariable-Number Tandem Repeat Analysis Reveals Genetic Relationships within Bacillus anthracis. Journal of Bacteriology 2000; 182(10): 2928-36.

5. Bush LM, Abrams BH, Beall A, et al. Index case of fatal inhalational anthrax due to bio-terrorism in the United States. N Engl J Med. 2001; 345(22): 1607-10.

6. Kort R, O'Brien AC, van Stokkum IHM, et al. Assessment of Heat Resistance of Bacterial Spores from Food Product Isolates by Fluorescence Monitoring of Dipicolinic Acid Release. Appl Environ Microbiol. 2005; 71(7): 3556-64.

7. Setlow P. Spores of Bacillus subtilis: their resistance to and killing byradiation, heat and chemicals. J Appl Microbiol. 2006; 101(3): 514-25.

8. Barr JR, Boyer AE, Quinn CP. Anthrax: modern exposure science combats a deadly, ancient disease. J Expo Sci Environ Epidemiol. 2010; 20(7): 573-4.

9. Mock M, Fouet A. Anthrax. Annu Rev Microbiol. 2001; 55(1): 647-71.

10. Spencer RC. Bacillus anthracis. J ClinPathol. 2003; 56(3): 182-7.

11. Nass M. The Anthrax Vaccine Program: An Analysis of the CDC's Recommendations for Vaccine Use. Am J. Public Health 2002; 92(5): 715-21.

12. Brachman PS, Gold H, Plotkin SA, et al. Field Evaluation of a Human Anthrax Vaccine. Am J. Public Health Nations Health 1962; 52(4): 632-45.

13. Wright $\mathrm{MH}$, Matthews $B$, Greene AC, et al. Growth inhibition of the zoonotic bacteria Bacillus anthracis by high antioxidant Australian plants: New leads for the prevention and treatment of anthrax. Phcog Commn. 2015; 5(3): 173-89.

14. Hart C, Ilanko P, Sirdaarta J, et al. Tasmannia stipitata as a functional food/ natural preservative: Antimicrobial activity and toxicity. Phcog commn. 2014; 4(4): 33-47.

15. Sautron C, Cock IE. Antimicrobial activity and toxicity of Syzygium australe and Syzygium leuhmanii fruit extracts. Phcog Commn. 2014; 4(1): 53-60.

16. Winnett $\mathrm{V}$, Boyer $\mathrm{H}$, Sirdaarta J, et al. The potential of Tasmannia lanceolata as a natural preservative and medicinal agent: Antimicrobial activity and toxicity. Phcog Commn. 2014; 4(1): 42-52.

17. Cock IE, Mohanty S. Evaluation of the antibacterial activity and toxicity of Terminalia ferdinandia fruit extracts. Phcog J. 2011; 3(20): 72-9.

18. Cock IE. Medicinal and aromatic plants-Australia. In Ethnopharmacology, Encyclopedia of Life Support Systems (EOLSS), 2011. Developed under the auspices of UNESCO. Oxford, UK: EOLSS Publishers; 2011. Available from: http://www.eolss.net. Accessed 1 April 2013

19. Lassak EV, McCarthyT. Australian medicinal plants. A complete guide to identification and usage. Reed New Holland Publishers Sydney Australia; 2011.

20. Cock IE. Antibacterial activity of selected Australian Native plant extracts. Internet Journal of Microbiology 2008; 4(2): 2.

21. Cock IE. Antimicrobial activity of Eucalyptus major and Eucalyptus baileyana methanolic extracts. Internet J Microbiol. 2009; 6(1):

22. Cock IE, Kukkonen L. An examination of the medicinal potential of Scaevola spinescens: Toxicity, antibacterial and antiviral activities. Phcog Res. 2011; 3(2): 85-94.

23. Cock IE. The phytochemistry and chemotherapeutic potential of Tasmannia lanceolata (Tasmanian pepper): A review. Phcog Commn. 2013; 3(4): 13-25.

24. Winnett V, Boyer H, Sirdaarta J, et al. The potential of Tasmannia lanceolata as a natural preservative and medicinal agent: antimicrobial activity and toxicity. Phcog Commn. 2014; 4(1): 42-52.

25. Rayan P, Matthews B, McDonnell PA, et al. Phytochemical analysis of Tasmannia lanceolata extracts which inhibit Giardia duodenalis proliferation. Pharmacognosy Magazine 2015; in press

26. Cock IE, Matthews B. Metabolomic profiling of antiviral Scaevola spinescens extracts by high resolution tandem mass spectroscopy. Acta. Horti. culturae 2015; in press.

27. Crago J, Cock IE, Kerr $P$, et al. Nature's helping hand-Scaevola spinescens, History and use in Western Australia. The maroon bush story. Aussie Outback Books Mt Helena, Australia; 2011.

28. Cock IE, Winnett $V$, Sirdaarta J, et al. The potential of selected Australian medicinal plants with anti-Proteus activity for the treatment and prevention of rheumatoid arthritis. Pharmacognosy Magazine 2015; 42(Sup 1): S190-208.

29. Coutts RH, Catterall CP. Identifying the plants of Toohey Forest. Ecos Educational Publishers Nambour, Australia; 1980

30. Courtney R, Sirdaarta J, Matthews B, et al. Tannin components and inhibitory activity of Kakadu plum leaf extracts against microbial triggers of autoimmune inflammatory diseases. Phcog J. 2015; 7(1): 18-31.

31. Arkhipov A, Sirdaarta J, Rayan P, et al. An examination of the antibacterial, antifungal, anti-Giardial and anticancer properties of Kigelia africana fruit extracts. Phcog Commn. 2014; 4(3): 62-76.

32. Maen A, Cock IE. Inhibitory activity of high antioxidant Australian native fruits against the bacterial triggers of selected autoimmune diseases. Phcog Commn. 2015; 5(1): 48-58.

33. Sirdaarta J, Matthews B, White A, et al. GC-MS and LC-MS analysis of Kakadu plum fruit extracts displaying inhibitory activity against microbial triggers of multiple sclerosis. Phcog Commn. 2015; 5(2): 100-5.

34. Cock IE, Ruebhart DR. Comparison of the brine shrimp nauplii bioassay and the Tox Screen-II test for the detection of toxicity associated with Aloe vera (Aloe barbadensis Miller) leaf extract. Pharmacognosy Research 2009; 1(2): 102-8. 
35. Chikowe G, Mpala L, Cock IE. Antibacterial activity of selected Australian Syzygium species. Phcog Commn. 2013; 3(4): 77-83.

36. Maughan $H$, Van der Auwera G. Bacillus taxonomy in the genomic era finds phenotypes to be essential though often misleading. Infection. Genetics and Evolution 2011; 11(5): 789-97.

37. Tourasse NJ, Helgason E, Okstad OA, et al. The Bacillus cereus group: novel aspects of population structure and genome dynamics. Journal of Applied Microbiology 2006; 101 (3): 579-93.

38. Priest FG, Barker M, Baillie LW, et al. Population structure and evolution of the Bacillus cereus group. Journal of Bacteriology 2004; 186(23): 7959-70.

39. Rasko DA, Altherr MR, Han CS, et al. Genomics of the Bacillus cereus group of organisms. FEMS Microbiology Reviews 2005; 29(2): 303-29.

40. Van Vuuren SF, Viljoen AM. Antimicrobial activity of limonene enantiomers and 1,8-cineol alone and in combination. Flavour and Fragrance Journal 2007 22(6): 540-4.

41. Hendry ER, Worthington T, Conway BR, et al. Antimicrobial efficacy of eucalyptus oil ana 1,8-cineol alone and in combination with chlorhexidine digluconate against microorganisms grown in planktonic and biofilm cultures. Journal of Antimicrobial Chemotherapy 2009; 64(6): 1219-25.
42. Narayana KR, Reddy MS, Chaluvadi MR, et al. Bioflavonoids classification, pharmacological, biochemical effects and therapeutic potential. Indian Journal of Pharmacology 2001; 33(1): 2-16.

43. Arima H, Ashida H, Danno GI. Rutin-enhanced antibacterial activities of flavonoids against Bacillus cereus and Salmonella enteritidis. Bioscience, Biotechnology and Biochemistry 2002; 66(5): 1009-4.

44. Buzzini P, Arapitsas P, Goretti M, et al. Antimicrobial activity of hydrolysable tannins. Mini-Reviews in Medicinal Chemistry 2008; 8(12): 1179-87.

45. Wolinsky LE, Sote EO. Isolation of natural plaque-inhibiting substances from Nigerian chewing sticks. Caries Research 1984; 18(3): 216-25.

46. Hogg SD, Embery G. Blood-group-reactive glycoprotein from human Saliva interacts with lipoteichoic acid on the surface of Streptococcus sanguis cells. Archives in Oral Biology 1982; 27(3): 261-8.

47. Wu-Yuan CD, Chen CY, Wu RT. Gallotannins inhibit growth, water-soluble glucan synthesis, and aggregation of Streptococci mutans. Journal of Dental Research 1988; 67(1): 51-5.

48. Doganay M, Metan G, Alp E. A review of cutaneous anthrax and its outcome. Journal of Infection and Public Health 2010; 3(3): 98-105.

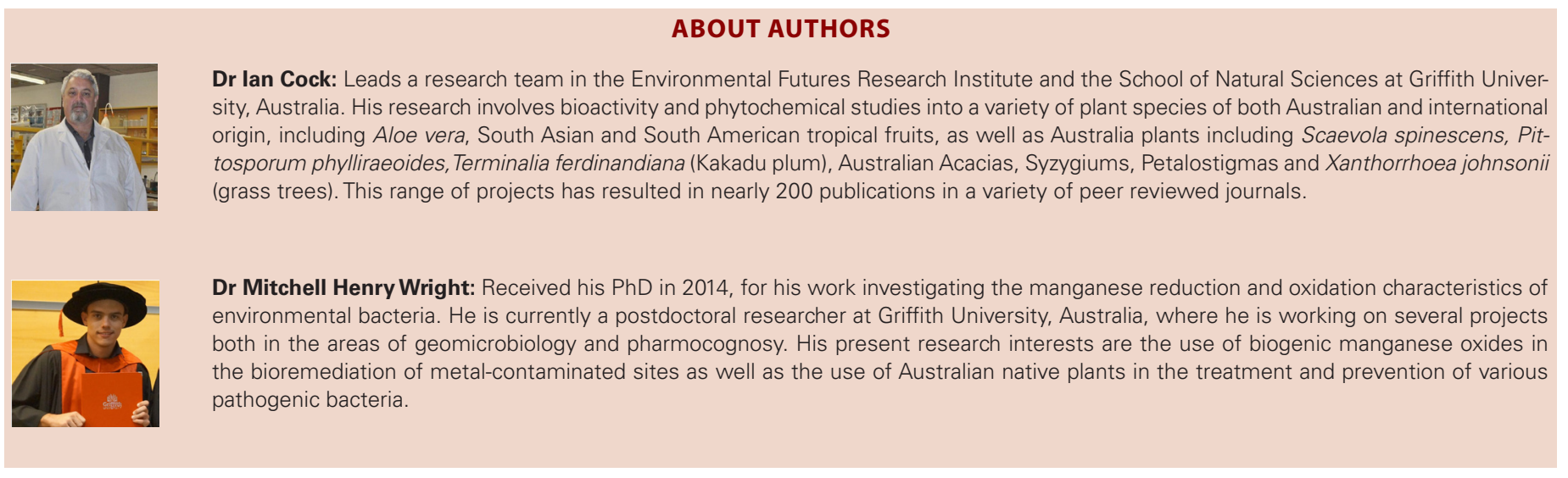

